\title{
The Research on the Ideological Education and Self-Discipline of College Students
}

\author{
Heming $\mathrm{Wu}$ \\ Shijiazhuang vocational technology institute, Shijiazhuang, China \\ XXXwu@163.com
}

\begin{abstract}
Keywords: Ideological Education, Self-Discipline, College Students
\end{abstract}
\begin{abstract}
College is a perfect ideological and moral and social consciousness of the critical period. Currently, students in the ideological and moral aspects to varying degrees, there is a lack of self-restraint, which determines when the ideological and moral education of college students need to exist external constraints. Furthermore, the purpose of ideological and moral education also determines the existence of the reasonable external constraints. Implementation of external constraints on college students to pay attention to human nature as the principle of self-discipline and combined with modest grasp of the arts, and the school and the family, society forms a restraining force.
\end{abstract}

\section{Introduction}

In recent years the practice a kind of trend in the ideological and moral education of concern: the absence of in-depth understanding of the concept of people-oriented education, as well as some Western educational thought misunderstanding, some people advocate the development of autonomy and creativity of college students at the same time, the educational methods on on the "external constraint" be denied, resulting in the lack of the necessary external constraints in the process of education of college students and even appeared to cater to, letting the students of the phenomenon. College students, as educated, their ideological level in the promotion stage, moral consciousness in the perfect stage, and college students in which age is a critical period of one world, life and values formation, if the lack of the necessary external constraints, most likely caused by an error generation college students attitudes and behavior, and even lead to extreme liberalism and egoism. Just as modern Russian philosopher Nikolai Berdiaev pointed out: "that freedom is the easy thing, and this is wrong freedom is a difficult thing."University education reform cannot go too far and cannot belittle role of external constraints. Lack of necessary external constraint education is not complete education, education and irresponsible.

\section{The Lack of Self-Restraint of College Students in Ideological and Moral Aspects}

College students are the country's valuable human resources. As the nation's moral condition for hope, the future of the motherland and it has been popular with college students to our community. Educators from surveys and studies, the mainstream of contemporary college students' ideological and moral situation is good, showing a positive, pragmatic, healthy, upward trend. However, some obvious weaknesses in the ideological and moral presence college students cannot be ignored, especially in terms of lack of self-restraint is particularly evident. In the following areas, we can see that the surface exhibited varying degrees of college students lack self-discipline.

They lack of self-restraint laws. Because the propulsion community legal education and legal knowledge in school learning, college students legal awareness is still relatively strong, but most only stay in the perceptual level, and "knowledge" and "line" there is a big contrast; Students' Legal Awareness uneven level. On the one hand, college students pick up the legal weapons to protect their legitimate rights and interests of the case after another; on the other hand, examples of college students and common crimes, theft, robbery or prostitution, rape, murder and other crimes, as well as assault, vandalism, plagiarism others It has occurred academic achievement, employment contracts 
and other acts of random tearing up. Some students mistakenly believe that they are students, "illegal," "criminal," these words are distant from their own, cannot use the law to restrain their behavior, and even the behavior of some students have violated the law when he still did not realize.

They lack of discipline of self-restraint. Although the quality of education in our country has been advocating for many years and have achieved some success, but most of the primary and secondary education enrollment rate is still in the guide, with the parents of "Succeed", "Wang Cheng-feng," the urgent desire, before entering the university, students free space is very small, less free time; there are students in primary and secondary schools have been around the "nanny" type of management, many students enter the university finally had a feeling "liberated", and ignoring school rules and regulations The phenomenon occurs when there is discipline. Comply with classroom discipline as a very basic and over ten years' college students who are familiar norms, there are many students difficult to comply with. In the university classroom can be seen eating, phone, chat, play games using a mobile phone or laptop computer, free access to the classroom, between indecent behavior and other acts in violation of classroom discipline, or even take place in the classroom to play poker thing. In contrast, reading extracurricular books, sleep has become a so-called acts very "civilized" in the. Students in recent years, due to cheating in examinations and disciplined by the school is not a minority, but each maturity, the final exam, students cheating unabated, cheating varied, and constantly "upgrade" from the past covert plagiarism, pass The answer to the use of communications equipment and other development cheating, plagiarism public, collective cheating and so on. Students in the treatment of a considerable part of the examination of the attitude that no matter in what ways and means, as long as can get a satisfactory score can be used.

They lack of moral self-restraint. College students who live in the real world, they cannot be affected. Secondly, most students now have only one child, parents and even pampered pet, as well as emphasis on intellectual parents and schools, light moral education, resulting in blurred college students' moral awareness. Again, college students are young, social experience shallow, less life experience, moral judgment is not strong. More than a few combined result is moral self-restraint did not play its due role in college students here, college students lack self-reflection and self-control. Industry is the traditional virtue of the Chinese nation, but in the eyes of some students, indolent has become "fashionable." They work the same as "no ability", "degrading" and thus reap the profits, something for nothing, willing. Some college students to predatory considered a "skill", "Glory", in individual students and even a "laugh poverty but not prostitution," the strange phenomenon. Hard work of thinking is fine revolutionary traditions of our party, but in the eyes of some college students that tradition has long been obsolete. They covet comfort and enjoyment, respected and be merry, eat pomp, speaking through upscale, play talk diversity, mutual competition, excessive consumption. Some students come from poor families are affected, regardless of the capacity of parents to borrow money but also high consumption.

\section{The School Education and Self-Restraint}

After the majority of college students is through pre-school, primary school, secondary school, college entrance examination after the baptism, entered the university campus. College life, learning environment with respect to the primary and secondary schools, has too much freedom and too little institutional constraints. There are many students not suited to this type of relaxed constraints sudden, like a runaway Mustang, gradually relax the self-supervision, grades plummeted, worse all night long addicted to online games, abandoned their studies, damage to health. CNNIC report shows that Chinese Internet users in the proportion of students up to $28 \%$, Chinese Academy of Sciences Institute of Psychology in 13 colleges and universities nationwide survey showed that $80 \%$ interrupted their studies (including drop out, drop out) college because Internet addiction. The longer the Internet time, when the network addiction, the online world of the individual spiritual satisfaction from the initial escape from reality in turn set up a virtual world and reality more and more out of tune, scenic surroundings has a negative attitude towards the online world The value realization, form inner anxiety, disorders of communication then there eventually exhibit very typical social alienation and 
other features. What, then is the focus on prevention is not to pay attention to, that help college students from the following aspects to establish a "Maintenance" thinking, enhance students' self-binding.

Use the good school education and the "Maintenance" education. Students started going to school before formal learning into life, with the military to carry out Cautiousness education, the school students should abide by the norms, institutions of learning, enable students to establish the rule concept.

In the study of life after the start, and guide the students career planning, conduct career planning competition, so that the students on their own how to spend college life have to think some planning. Not direction and goals.

Use outstanding student model demonstration to enhance the appeal of morality. Value-oriented college students' vulnerable groups affected. School, community college students form values, it should play a leading role by playing the role of spiritual leader of outstanding student standards and top students to establish a modern, etc. "Gentleman" criteria.

Use college students' self-management system. Groups of students self-management organizations should be able to give full play to students' self management functions, promote student autonomy, self-discipline, self-care, develop self-reliance, and promote student learning to know, learning to do, learn to live, learn development, the key is the formation of a scientific Student groups organized system of self-management. We should give full play to the system of classes, clubs, student government and other student self-management, self-education provided by the internet. So that more students to display their management skills, leadership opportunities, and training students cadres of leadership and cohesion, in order to establish a positive appeal.

Design and improve students' self-binding evaluation system. Help students improve the ability of self-discipline and self-management, self-discipline through physical quantification, and to achieve more concrete reminder mechanism. And strong efforts to promote use of the network, carried out propaganda in students, in order to play a more active role.

\section{The Research on Ideological and Moral Education and Self-Discipline}

Ideological and moral education is essentially borne by a certain society, aimed at promoting individual realization of the educational social activities. Individual socialization is important to realize the purpose of ideological and moral education. Socialization of individuals, not only is important for society, for individuals also extremely important. This is because "people are the most truly political animal, is not only a gregarious animal, but only in society in order to separate the animals." The person's life is in the process of socialization, and universities stage is a critical period of human socialization. Students in this period to complete the transition to adult adults never completed from student to professional people change. Therefore, we must allow students to understand, "my own existence is a social activity; so, I personally do what I did personally for society, because I know that he is a community of people."

At the university level, students who want to understand and master a large number of operating rules and mainstream social values, and on this basis, put them into their own inner thoughts and motives, so that their actions are consistent with the requirements of society and conducive to the development of society. In a sense, the socialization process is the learning process. This process is a gradual understanding, master, skilled in the process, in this process, "Error" is inevitable. In the "correction" in the process, external constraints educators are essential. If you lack the necessary external constraints, the students will take more social detours, to spend more time, cost more. It was with the educators who constantly revised, college students can be successfully socialized to become "able to adapt to and participate in the political life of certain social and spiritual life, organizational life, fulfill certain social role of man" 


\section{The Combination of the External Constraints and the Self-Restraint}

Self-restraint, referring to the conscious use of the law, discipline, rules and ethics to restrain themselves regulate and control their own behavior. External constraints and self-restraint are interrelated and mutually reinforcing aspects. There is no doubt, improve the ideological and moral standards of students, is inseparable from the necessary external constraint, but not their acceptance, understanding and practice, external constraints cannot be achieved. Ideological and moral education requires not only external constraints teach correct thinking, correct errors of behavior, more importantly, the students themselves through movement and ideological contradictions of social practice, that self-discipline to achieve overcome wrong ideas with correct ideas, replace with the correct behavior of the wrong behavior of purpose. Educators should be adept at methods Students' self-restraint, to promote their conduct active ideological and moral education.

Meanwhile, the ability of students to self-discipline is the outer formed and developed under the influence of constraints, the ability to cultivate only through external constraints and the development of self-restraint. The development of self-discipline, and in turn encourage students to better and more consciously accept the influence of external constraints, strengthen and consolidate the results of education. Therefore, the relationship between external constraints and self-restraint, is the relationship between internal thought and external students moral education, is the relationship between means and ends. The purpose of education is not education in order to achieve the purpose of the external constraint is ultimately necessary so that students have self-regulation, self-control. If every student can consciously self-restraint, consciously control their own behavior, then the whole idea of moral standards Students will be greatly improved.

\section{Conclusion}

College students are a vibrant community, the majority of this group is currently 90, is a group full of personality. Improve college students' self-discipline, to achieve college students self-management, self-education to improve the quality of higher education plays a vital role.

\section{References}

[1] B. N. Ma, The legal problems of commercial bank financial products, J. Modern Law. 44 (2010) 146-147.

[2] H.X.Zeng, The cause of college students' internet addiction, J. Educational Research. 18(2005) 55-57.

[3] J.H.Xue, The college students self-management system, J. Jiangsu Educational Research, 32(2012) 189-190.

[4] Y.J.Qi, The Students' self-management, J, Teaching and Management, 4(2007) 38-40.

[5] Y.M.Tian, The Self-management for University Students, J. Youth Exploration, 9(2013) 142-150. 